\title{
Neoliberal-neoconservative feminism(s) in Turkey: politics of female bodies/ subjectivities and the Justice and Development Party's turn to authoritarianism
}

\section{Betül Yarar}

\begin{abstract}
Studying changes in the Justice and Development Party's (AKP) politics within the general context of the long-lasting history of neoliberalismneoconservatism in Turkey, this paper aims to provide a new perspective for analyzing the party's recent drift to authoritarianism from the perspective of its gender politics. For many feminist scholars and activists, the recent changes in the AKP's gender politics are a matter of an increase in the AKP's oppression and patriarchal power. These analyses give no explicit account of why there has been an increase or if it is only a matter of an increase in the level of the oppressiveness of patriarchal power. From a perspective that questions this quantitative assumption (i.e. with an argument that the AKP's politics has been equally oppressive for all women and from the very beginning of its rule), this paper aims to give insights into this complex process which led, first, to the emergence of neoliberal feminism as a new subjective position, and, later, to the modification of this official politics on women's issue and the emergence of neoconservative feminism along with the AKP's drift to authoritarianism in response to certain contradictory effects of neoliberalism and its eventual crisis.
\end{abstract}

\section{Introduction}

The political climate of the post-Kemalist era since the late 1970s has led the second-wave feminist movement and Islamic movement to not only emerge as

Betül Yarar, The University of Bremen, Faculty of Pedagogy and Educational Sciences, Intercultural Education Branch, email: betyarar@gmail.com.

New Perspectives on Turkey, no. 63 (2020): 113-137 C The Author(s), 2020. Published by Cambridge University Press in association with New Perspectives on Turkey. This is an Open Access article, distributed under the terms of the Creative Commons Attribution-NonCommercial-ShareAlike licence (http://creativecommons.org/licenses/by-nc-sa/4.o/), which permits non-commercial re-use, distribution, and reproduction in any medium, provided the same Creative Commons licence is included and the original work is properly cited. The written permission of Cambridge University Press must be obtained for commercial re-use. 
distinct identity movements but also interact with each other, which in turn resulted in the eventual emergence of new political positions like "Islamic feminism" in Turkey. The interaction between Islam and feminism has not been unidirectional, as some scholars have developed new concepts aiming to understand Islam from a perspective that considers Islam as not inherently regressive in its effects on the modernization process. For instance, Nilüfer Göle argues that Islam as a social phenomenon can have progressive insights, particularly as opposed to the forced modernization and secularization processes dictated by the Kemalist establishment in modern Turkey. ${ }^{1}$ This liberal view of Islam and Islamism has gained further strength during the rule of the Justice and Development Party (AKP). ${ }^{2}$ Due to its pro-European Union (EU) politics, the AKP was assumed to have the capacity to combine an Islamic view with democratic social forces that would bring further democracy to Turkey. This perspective had also been embraced, despite some reservations, by the Kurdish movement and by feminists to the extent that the AKP's politics expanded their hopes for EU membership, the protection of women's human rights, and a successful peace process. It was under these circumstances that Islamist conservatives (including politicians) appropriated strategic elements of liberal feminism like women's rights and gender equality, which in turn strengthened its neoliberal position blending liberal aspects with conservative-Islamic views and elements.

In contrast to this liberal approach, Kemalists object to the AKP by associating it with Islamist fundamentalism. This position overlaps with the position of some Marxists and socialist feminists ${ }^{3}$ who considered liberal aspects of AKP politics as not sincere but as takiye (dissimulation). They argue that the AKP's project is a product of global capitalism or a project of imperialist powers. In line with this approach, a group of socialist feminist scholars has also argued that this liberal atmosphere made some feminists blind not only to economic-class dimensions and the regressive outcomes of the AKP's politics but also to their destructive impacts on women's lives and to how they strengthen the patriarchy. Following Fraser, ${ }^{4}$ who states that ideals pioneered by second-wave feminists are now serving quite different ends

1 Nilüfer Göle, Modern Mahrem (Istanbul: Metis Yayınları, 1991); Nilüfer Göle, İslamın Yeni Kamusal Yüzleri (Istanbul: Metis Yayınları, 2000).

2 İhsan Dağı, "The Justice and Development Party: Identity, Politics, and Discourse of Human Rights in the Search for Security and Legitimacy," in The Emergence of a New Turkey: Democracy and the AK Parti, ed. H. Yavuz (Salt Lakey: Utah University Press, 2006), 88-106; Ziya Öniş, "Sharing Power: Turkey's Democratization Challenge in the Age of AKP Hegemony," Insight Turkey 15, no. 2 (2013): 103-22.

3 Simten Coşar and Gamze Yücesan-Özdemir, iktidarın Şiddeti: AKP'li Yıllar, Neoliberalizm ve Islamcı Politikalar (Silent Violence: Neoliberalism, Islamist Politics and the AKP Years in Turkey) (Ankara: Metis Yayınevi, 2014).

4 Nancy Fraser, "Feminism, Capitalism and the Cunning of History," New Left Review 56, March-April (2009): 97-117. 
and that our critique of sexism now provides the justification for new forms of inequality and exploitation in neoliberal times, these feminists also argue against poststructuralist feminism for being unable to comprehend how neoliberal politics including those of the AKP have appropriated and even abused some feminist arguments. ${ }^{5}$

In contrast to these two positions, this article expands on a theoretical framework which is mainly based on the Foucauldian theory of power and Gramscian theory of hegemony. In line with this, in addition to some poststructuralist and Foucauldian feminist analyses, ${ }^{6}$ the article follows some feminist analyses that address the heterogeneous character of the AKP's policies and discourses targeting women. ${ }^{7}$ Hence the paper avoids the negative and reductionist conception of power that attributes power to a single structure (i.e. the state, family, economy) or a group that supposedly holds absolute power and acts as the main determinant factor over all socio-historical dynamics. Aiming to analyze the gender dimension of the AKP's political turn to authoritarianism that took place in the late 2000s, the paper refuses also to construct a causal relationship between the two scopes of analysis (as Kandiyoti states the first is the identification of regime type and the second is the politics of gender) and to see the two parallel tracks of an inquiry (the former always deepens or strengthens the latter in a progressive manner). Instead, the paper calls for a more precise identification of the various ways

5 Görkem Akgöz, "Mutsuz Evlilikten Tehlikeli Flörte: Feminizm, Neoliberalizm ve Toplumsal Hareketler," Fe Dergi 8, no. 2 (2016): 86-100; Özlem Akşit, "Neoliberalizm Feminizmi Nasıl Kullanıyor?" Pazartesi, June 19, 2017; Simten Coşar and İnci Özkan-Kerestecioğlu, "Feminist Politics in Contemporary Turkey: Neoliberal Attacks, Feminist Claims to the Public," Journal of Women, Politics \& Policy 38, no. 2 (2016): 151-74; Simten Coşar and Metin Yeğenoğlu, "New Grounds for Patriarchy in Turkey? Gender Policy in the Age of AKP," South European Society and Politics 16, no. 4 (2011): 555-73; Aynur Özuğurlu, "Neoliberalizm ve Feminist Politikada 'Sınıfsal Tutum' Arayışları," Ankara Üniversitesi SBF Dergisi 67, no. 4 (2012): 125-46; Aynur Özuğurlu, ed., 21. Yüzyıl Feminizmine Doğru: Neoliberalizmin Ötesinde Bir Kadın Hareketi Için Tartışmalar (Ankara: NotaBene Yayınları, 2013).

6 Özlem Aslan and Zeynep Gambetti, "Source Provincializing Fraser's History: Feminism and Neoliberalism," History of the Present 1, no. 1 (Summer 2011): 130-47; Feride Acar and Gülbanu Altunok, "The 'Politics of Intimate' at the Intersection of Neo-liberalism and Neo-conservatism in Contemporary Turkey," Women's Studies International Forum 41 (2013): 14-23; Dilek Cindoğlu and Didem Unal, "Gender and Sexuality in the Authoritarian Discursive Strategies of 'New Turkey'," European Journal of Women's Studies 24, no. 1 (2016): 39-54; Deniz Kandiyoti, "Locating the Politics of Gender: Patriarchy, Neoliberal Governance and Violence in Turkey." Research and Policy on Turkey 1, no. 2 (2016): 103-18; Zeynep Kurtuluş Korkman, "Blessing Neoliberalism: Economy, Family, and the Occult in Millennial Turkey," Journal of the Ottoman and Turkish Studies Association 2, no. 2 (2015): 335-57.

7 See Ayşe Güneş Ayata and Fatma Tütüncü, "Party Politics of the AKP (2002-2007) and the Predicaments of Women at the Intersection of the Westernist, Islamist and Feminist Discourses in Turkey," British Journal of Middle Eastern Studies 35, no. 3 (2008): 363-84; Başak Akkan, "Politics of Care in Turkey: Sacred Familialism in a Changing Political Context", Social Politics: International Studies in Gender, State and Society 25, no 1 (Spring 2018): 72-91. 
in which the politics of gender are intrinsic, rather than incidental, to a characterization of the AKP's politics. The paper also analyzes the AKP's politics and gender politics at the conjunction and complex matrix of neoliberalism and neoconservatism and the contradictory impacts of these two rationalities that are considered not only suppressive but also constitutive of various subject positions and institutional forms. In this sense, the AKP's politics are considered as nonhomogeneous but complex articulations of different narrative lines that have been adopted in response to the unstable context of political struggles. Also, the AKP's political projects are neither reduced to economic strategies nor perceived as uniformly bad for all women. ${ }^{8}$ In this sense, the paper does not see a linear and progressive development, enhancement, or strengthening of capitalist and patriarchal powers during the AKP's rule, but as ongoing power struggles which led to the emergence of qualitative changes in the AKP's hegemonic strategies as well as its gender politics correspondingly since the late 2000s in Turkey. While the Foucauldian theory of power enables this microscopic zoom to the gendered dynamics of the AKPs changing modes of governance, the Gramscian theory of hegemony helps to contextualize such an analysis within the history of political struggles.

In line with all these, the second section analyzes the earlier period of the AKP's politics and how "neoliberal feminism" has emerged as a new subjective position under the impact of diverse social forces mobilized and/or orchestrated by the AKP government. It also underlines how this mode of feminism played a cementing role in the constitution of the earlier liberal power block and social consensus around the AKP's political project of "Conservative Democracy." The final section focuses on changes in the AKP's politics in parallel with the global crisis of "neoliberalism with a human face" toward the end of the 2000s and with the dismantling of the earlier liberal social consensus. Like many other populist authoritarian parties and regimes around the world, the AKP responded to the growing economic and political crisis by appealing to radical conservative and nationalist authoritarian forces. Its drift to this new authoritarian position occurred in parallel with changes in its gendered institutional and discursive strategies that I framed with the concept of "neoconservative feminism." The latter emerged in a very destructive and oppositional manner against secular queer and feminist politics in Turkey. Whether the AKP's authoritarian regime in this later period has successfully contaminated or controlled the neoliberal crisis and managed to constitute a new and relatively stable regime - and if so how we can define the new regime - are questions that go beyond the aim and scope of this article.

8 Diane Elson, "Male Bias in Structural Adjustment," in Women and Adjustment Policies in the Third World, eds. H. Afshar and C. Dennis (New York: St Martin's, 1992), 46-68. 


\section{On theory and method: positive-constitutive power and feminist discussion on neoliberal governmentality}

Foucault pursues a modern notion of power that is noncoercive, decentralized, pervasive, and productive. In this sense, power operates via producing knowledge and truth claims about our own subjective and objective realities. ${ }^{9}$ Avoiding conceptualizing power as something posed by way of "episodic" or "sovereign" acts of domination and coercion, Foucault shows, through the genealogy of modern power, that it is neither an essentially negative nor a repressive force that operates purely through mechanisms of law, censorship, suppression, and violence, ${ }^{10}$ but it is rather exercised for each (individual) and all (social) simultaneously through dispersed mechanisms, fields, and subject positions that are regulated normatively and procedurally as much as hierarchically and oppressively. As McLaren ${ }^{11}$ states, some feminists disagree on the usefulness of Foucault's works for feminist theory and practice due to his negligence in theorizing the notion of female resistance, agency, and subjectivity. ${ }^{12}$ On the contrary, many poststructuralist and queer feminists who work with Foucault's theory of power suggest that addressing patriarchal power and women's freedom requires considering its positive impacts on the internal dynamics of constituted subjectivities. At this point one can refer to the contribution of Butler ${ }^{13}$ via her related analysis of subjectivities as positive effects of power.

This brings us to the understanding of power concerning the concept of governmentality or governing rationality which enables us to think of power as part of our strategic conduct with others as much as with ourselves. Many Foucauldian authors emphasize that individuals exercise power to govern themselves and others in dispersed fields of practice based on certain modes of thinking or governing rationalities. ${ }^{14}$ To contextualize such an analysis of power in its institutional and subjective terms one can make use of the

9 Michel Foucault, Discipline and Punish: The Birth of the Prison (London: Penguin, 1978); Michel Foucault, "On the Genealogy of Ethics: An Overview of Work in Progress," in Ethics, Subjectivity and Truth: The Essential Works of Foucault, 1954-1984 Volume 1, ed. Paul Rabinow, trans. Robert Hurley et al. (New York: The New Press, 1997); Michel Foucault, The History of Sexuality: The Will to Knowledge (London: Penguin, 1998).

10 Michel Foucault, The History of Sexuality Volume I: An Introduction, trans. Robert Hurley (New York: Pantheon Books, 1978), 82.

11 A. Margaret McLaren, Feminism, Foucault, and Embodied Subjectivity (Albany, NY: SUNY Press, 2007).

12 Monique Deveaux, "Feminism and Empowerment: A Critical Reading of Foucault Author(s)," Feminist Studies 20, no. 2 (1994): 223-47; Lois McNay, Foucault and Feminism: Power, Gender and the Self (Cambridge: Polity Press, 1992).

13 Judith Butler. Gender Trouble: Feminism and the Subversion of Identity (London: Routledge, 1990-2006).

14 Thomas Lemke "'The Birth of Bio-politics': Michel Foucault's Lecture at the Collège de France on Neo-liberal Governmentality," Economy and Society 30, no. 2 (2001): 109-207. 
Gramscian theory of hegemony since it focuses more on power struggles in relational and periodical terms (i.e. periods involving a war of positions or organic crisis) ${ }_{+}^{15}$ As McGuire states, the Gramscian concept of hegemony, similar to Foucault's notion of power, encompasses a deeper meaning than just a ready moniker for local, global, or regional domination. ${ }^{16}$ For Laclau and Mouffe, Hall and O'Shea, ${ }^{17}$ and many others, hegemony refers not to a static state of domination but to a process that results in only relative stability but never fixity in power relations and struggles.

One common concept among Foucauldian authors in relating his theory of power to the recent global socio-political context is neoliberalism as a mode of governmentality or rationality. Neoliberalism as a concept has been popularly used also by socialist feminists who recently asserted a widespread view that neoliberalism has managed to be globally hegemonic by appropriating the critical discourses of new social movements, including the second-wave feminist movements. These socialist feminists blame poststructuralist theories for the defeat of second-wave feminist politics by neoliberalism ${ }^{18}$ by missing the economic and class dimensions of neoliberalism and its destructive impacts on women and societies and for putting too much emphasis on the cultural aspect of neoliberal transformation. Contrary to this view, poststructuralist authors ${ }^{19}$ consider neoliberalism as a rationality that cannot be conceived only

15 See for instance Joseph A. Buttigieg, "Gramsci on Civil Society," Boundary 2 22, no. 3 (1995): 1-32; Joseph A. Buttigieg, "Contemporary Discourse on Civil Society: A Gramscian Critique," Boundary 2 32, no. 1 (2005): 33-52.

16 John Thomas McGuire, "Social Justice Feminism and Its Counter-Hegemonic Response to Laissez-Faire Industrial Capitalism and Patriarchy in the United States, 1899-1940," Studies in Social Justice 11, no. 1 (2017): 48-64.

17 Ernesto Laclau and Chantale Mouffe, Hegemony and Socialist Strategy: Towards a Radical Democratic Politics (London and New York: Verso, 1985); Stuart Hall and Alan O'Shea, "Common-Sense Neoliberalism," Soundings 55 (2013): 9-25.

18 Nancy Fraser, "Feminist Politics in the Age of Recognition: A Two-Dimensional Approach to Gender Justice," Studies in Social Justice 1, no. 1 (2007): 23-35; Fraser, "Feminism, Capitalism"; Nancy Fraser, Fortunes of Feminism: From State-Managed Capitalism to Neoliberal Crisis (London and New York: Verso, 2013); Sylvia Walby, The Future of Feminism (Cambridge: Polity Press, 2011); Hester Eisenstein, Feminism Seduced: How Global Elites Use Women's Labor and Ideas to Exploit the World (Boulder, CO: Paradigm Publishers, 2009).

19 Wendy Brown, "Neoliberalism and the End of Liberal Democracy," in Edgework: Critical Essays on Knowledge and Politics, 37-59 (Princeton: Princeton University Press, 2009); Wendy Brown, "American Nightmare: Neoliberalism, Neoconservatism and De-democratization," Political Theory 34, no. 6 (December 2006): 690-714; Wendy Brown, "Neoliberalism's Frankenstein: Authoritarian Freedom in Twenty-First Century 'Democracies'," Critical Times 1, no. 1 (2018): 60-79; Linda Colley and Catherine White, "Neoliberal Feminism: The Neoliberal Rhetoric on Feminism by Australian Political Actors," Gender Work and Organization 26, no. 8 (August 2019): 1083-99; Kate Gleeson, "Abortion and 'Choice' in the Neoliberal Aftermath," Politics and Culture: Materialist Feminisms Against Neoliberalism (March 9, 2014), https://politicsandculture.org/2014/03/09/abortion-andchoice-in-the-neoliberal-aftermath-by-kate-gleeson/; Johanna Oksala, "Feminism and Neoliberal Governmentality," Foucault Studies 16 (2013): 32-53; Catherine Rottenberg. "The Rise of 
as destructive but also constructive. This approach allows us to recognize neoliberal rationality's capacity of appropriating feminist arguments, offering new subjective positions and constructing new institutional strategies and not only seeking to suppress women and deteriorate the social state. For instance, according to Gleeson and Oksala, neoliberal governmentality cannot be conceived externally or as a mode of relations between preconstituted subjects. As Oksala states, assessing the impact of neoliberal governmentality requires rethinking our conceptions of female subjectivity, citizenship, political action, and feminist liberation since neoliberal governmentality has spread and intensified to the extent that not only have women come to be seen, but see themselves, increasingly as neoliberal subjects. ${ }^{20}$ For Rottenberg, neoliberal feminism, which became part of American popular culture in the 2010s, is a process through which women's liberation has been framed in extremely individualistic terms, consequently ceasing to raise the specter of social or collective justice. ${ }^{21}$ She argues that, "Unlike classic liberal feminism whose raison d'être was to pose an immanent critique of liberalism, [ . . ] this new feminism seems perfectly in sync with the evolving neoliberal order." 22 "[N]eoliberal feminism hollows out the traditional power of feminism to illuminate and critique the structural contradictions of liberal democracy, whose proclamations of universal rights and equality have historically excluded women in significant ways." ${ }^{23}$ Neoliberal feminism also initiates the emergence of an individuated feminist subject who is, on the one hand, feminist to the extent that she is distinctly aware of current inequalities between men and women, and, on the other hand, simultaneously neoliberal as she disavows the social, cultural, and economic forces producing this inequality. It is not a collectivist but an individuated subject who takes full responsibility for her well-being and self-care. Colley and White ${ }^{24}$ add that, as opposed to the state feminism of earlier periods, neoliberal feminism promotes a market-based approach to feminism and emphasizes mainly the economic empowerment of women. "The neoliberal feminist subject is thus mobilized to convert continued gender inequality from a structural problem into an individual affair" ${ }^{25}$ and define the

Neoliberal Feminism," Cultural Studies 28, no. 3 (2014): 418-37; Catherine Rottenberg, "The Neoliberal Feminist Subject," LARB (Los Angles Review of Books), January 7, 2018; Allison Phipps, The Politics of the Body: Gender in a Neoliberal and Neoconservative Age (Cambridge: Polity Press, 2014); Jana Sawicki, "Foucault and Feminism: Towards a Politics of Difference," Haypatia 1, no. 2 (1986): 23-36; Angela McRobbie, The Aftermath of Feminism: Gender, Culture and Social Change (London: Sage, 2010).

21 Rottenberg. "The Rise of Neoliberal," 419.

22 Ibid., 419.

23 Ibid., 420.

24 Colley and White, "Neoliberal Feminism."

25 Rottenberg, "The Rise of Neoliberal," 420. 
antidote of the existing problems of women in market terms. "Paradoxically (and counterintuitively), childcare, domestic works and harmonious family life that are posited as part of this new feminism's normative trajectory, fall squarely on the shoulders of individual women. Hence crafting a felicitous work-family balance becomes the ultimate ideal of a neoliberal feminist." 26

Neoliberal feminism shows a wider spectrum of neoliberal and neoconservative feminist positions as it includes or articulates diverse narrative lines ranging from liberalism to conservatism and nationalism. Whether this signifies a moment of feminism's experience of resurgence ${ }^{27}$ or the emergence of postfeminist era, ${ }^{28}$ or both, ${ }^{29}$ is an important issue that requires wider discussion. But here I followed Ringrose's understanding ${ }^{30}$ of postfeminism as a temporal, political, and theoretical representational terrain, in which both an anti-feminist or anti-genderist "backlash" and postmodernist, postfoundationalist moves to destabilize and deconstruct gender operate together. In this sense, the period of postfeminism is defined by the pluralization of feminism, not by its total failure or disappearance, and by its transformation into a subject of conflicts among various feminist, postfeminist and anti-feminist standpoints. We are going through a period of post-neoliberal feminism where anti-feminist standpoints take the lead and neoconservative feminist arguments have become massive and destructive against all alternative feminist standpoints.

As Brown states, the emergence of new and destructive forces has a deep connection with the long-lasting hegemony of neoliberal rationality in governance, which has not only resulted in new conservative gender subjectivities (ranging from neoconservative feminisms to toxic masculinities), but also institutional forms that would ascribe wider legitimacy to recent radical rightwing forces in the USA as well as in other parts of the world. Referring to the anti-political nature of neoliberalism, Brown also argues that "neoliberalism casts the political and social spheres both as appropriately dominated by market concerns and as themselves organized by market rationality." ${ }^{31}$ Here the state does not only construe itself in market terms but develops policies and promulgates a political culture that figures citizens exhaustively

26 lbid., 420.

27 Colley and White, "Neoliberal Feminism."

28 S. Jaworska and R. Khrisnamurthy, "On the F Word: A Corpus-based Analysis of the Media Representation of Feminism in the British and German Press Discourse, 1990-2009," Discourse and Society 23/4 (2012): 401-31; McRobbie, "Notes on Postfeminism."

29 Rottenberg, "The Rise of Neoliberal."

30 Jessica Ringrose, "Successful Girls? Complicating Post-Feminist, Neoliberal Discourses of Educational Achievement and Gender Equality," Gender and Education 19, no. 4 (2007): 471-89. See also Phipps, The Politics of the Body.

31 Brown, "American Nightmare;" Brown, "Neoliberalism's Frankenstein," 694-95. 
as rational economic actors in every sphere of life. The saturation of the state, political culture, and the social with market rationality effectively strip commitments to political democracy from governance concerns and political culture. $^{32}$ Within this context, in parallel with Rottenberg, Colley, and White, Brown also sharply addresses the depoliticizing and decontextualizing impacts of neoliberalism that make structural aspects of inequalities invisible, and legitimize the radical detachment of the government from socio-political responsibilities. Although neoliberalism has some references to liberal concepts and principles like liberty, freedom, and rights, these concepts lose their earlier political basis through the prism of neoliberalism. Brown further states that the major de-democratic effect of neoliberalism opens these principles to be abusively used by various conservative and anti-democratic forces. ${ }^{33}$ Although it seems contradictory, according to Brown neoliberalism and neoconservatism converge at crucial points to extend "a cannibalism of liberal democracy already underway from other sources in the past half century." ${ }^{24}$ While operating in different semiotic registers at the conjunction of these two concordant rationalities, notions like egalitarianism, civil liberties (including women's rights), fair elections, and the rule of law lose their original political meaning and turn into symbols or instruments to be used by various radical forces. Although Brown considers and defines the present, populist authoritarian regimes like that of Trump in neoliberal terms, there are some criticisms against her insistence on conceiving them as neoliberal. But what is important for the analysis here is to see how neoliberalism provides appropriate conditions for the emergence of such regimes rather than how to define them.

In line with the above-explained theoretical framework, in this paper the AKP's gender politics are scrutinized in the context of the long history and combined impacts of neoliberalism and neoconservatism in Turkey. Within this context one can investigate the transformation of the AKP's earlier project of liberal Islam or "Conservative Democracy" to nationalist Islam or the "one flag, one state, one land" project from the perspective of its gender politics. Within this context, in the AKP's politics and the statements of AKP politicians one can also discover some traces of how neoliberal feminism appeared and made room for itself without destroying already existing alternative feminist discourses and positions ${ }^{35}$ in the first period of its rule, and how in the second period it has transformed into a neoconservative mode which claims to be the only truth of women's bodies and sexualities as opposed

32 Ibid., 695.

33 Ibid.

34 Brown, "American Nightmare", p. 691.

35 Melinda Negrón-Gonzales, "The Feminist Movement During the AKP Era İn Turkey: Challenges and Opportunities." Middle Eastern Studies 52, no. 2 (2016): 198-214. 
to other secular feminist and queer positions. Such an analysis of the AKP's policies and discourses on women's issues first involves a search of certain concepts playing a key role in the AKP's gender politics (e.g* women's rights, women's empowerment, gender equality, equal opportunities for women and men, and women's poverty). Matching these concepts with certain influential politicians in the discourse yielded a broad collection of literature, including newspaper articles and news reports, other than the official documentation of the AKP. I reviewed this literature in chronological order using the method of discourse analysis. Here a large collection of documents has been reviewed based on concepts such as gender, women, equality, justice, rights, and feminism.

\section{The AKP's "Conservative Democracy" project and the emergence of neoliberal feminism}

Since the AKP came to power in 2002 it has implemented its political project of "Conservative Democracy," as its leading intellectuals have consistently termed it. ${ }^{36}$ This project refers to a peculiar amalgam of liberal, conservative-Islamic, and nationalist narrative lines that are articulated by neoliberalism. It relies on a critique of the old Kemalist modernization project, as opposed to which it offers an alternative modernization model that is in harmony with traditional Islamic values and neoliberal austerity rules at once. Tuğal comments that in the case of Turkish neoliberalization the Islamist religious opposition to neoliberalism was muted and secular opposition further marginalized and labeled as "anti-democratic." As a result, free market policies were deepened and intensified, turning Turkey into a neoliberal "success story" at national and global scales. ${ }^{37}$

Reflecting a heterogeneous character both in terms of its political discourse and coalition constituted among "liberals," "moderate" Islamists, and some Islamic nationalists, this new political regime in Turkey parallels the neoliberal regimes of the late 1990s defined as "neoliberalism with a human face" or a "Christian socialist face" in the West. ${ }^{38}$ Although neoliberalism was imposed

36 Yalçın Akdoğan, AK Parti ve Muhafazakar Demokrasi (İstanbul: Alfa Yayınları, 2004), 26.

37 Cihan Tuğal, "Fight or Acquiesce? Religion and Political Process in Turkey's and Egypt's Neoliberalizations, Development and Change", International Institute of Social Studies 43, no. 1 (2012): 23-51.

38 Bob Jessop, "New Labour or the Normalization of Neoliberalism," British Politics 2, no. 3, (2007): 282-8; Bob Jessop, "The Third Way: Neo-Liberalism with a Human Face?" in New Labour und die Modernisierung Gross Britanniens, eds. Sebastian Berg and Andre Kaiser (Augsberg: Wissener Verlag, 2006), 333-66; see Maxíne Molyneux, "The 'Neoliberal Turn' and the New Social Policy in Latin America: How Neoliberal, How New?" Development and Change 39, no. 5 (2008): 775-97. 
from above, in Turkey it came to be embraced in the name of Islam and democracy as opposed to centralized Kemalist establishments. Based on its populist-conservative pro-people stance, the party claims to be in the service of people as opposed to the top-down "social engineering projects" of the secular establishment, and hence manages to get votes from a large portion of the population, a majority of whom has a lower-class background. It is also known that the party receives great support from female voters (mainly housewives). ${ }^{39}$

Since the late 1980s in this post-Kemalist period, the critique of the Kemalist modernization project was the common epistemic field and political ground among not only neoliberals and neoconservatives ${ }^{40}$ but also progressive-libertarian social movements. ${ }^{41}$ On this basis, there has been some interactions among women's movement, ${ }^{42}$ Islamic movement, and Kurdish movement, which led for instance to the emergence of Islamic feminism sensitive to women's rights. ${ }^{43}$ It is known that some of these feminists have later participated in the AKP's cadres ${ }^{44}$ and introduced feminist political arguments and views into the party's politics. Hence neoliberal feminism as a complex patchwork of regulatory narratives on women's issues at the conjunction of Westernism, Islamism, feminism, liberalism has emerged. ${ }^{45}$ The AKP's sui generis gender politics, which was not only restrictive and suppressive but also productive and constitutive, has been a product as well as producer of this new political perspective.

An analysis of official party documents and public statements of the AKP politicians reflects the basic parameters of the AKP's gender politics and its earlier neoliberal feminism. In the first election declaration and in the 58th Government's Program of the AKP, it is stressed that women could not gain the footing they deserve although they share the burden of life with men and all the policies to be implemented would consider this situation. The elimination of women's problems was referred to as a priority in the same program to

39 See the survey conducted by A\&G on the 2009 local elections ("AKP Işsizlik, Kriz ve Üsluptan Kaybetti," Milliyet, April 13, 2009, http://www.milliyet.com.tr/siyaset/akp-issizlik-kriz-veusluptan-kaybetti-1082266). For the large percentage of housewives voting in favor of the AKP see "Ev Kadınları AK Parti'ye Oy Veriyor," Internet Haber, March 10, 2013, https://www. internethaber.com/ev-kadinlari-ak-partiye-oy-veriyor-511327h.htm.

40 See Yankaya's analysis of the self-ethic of the neoconservative bourgeoisie which has evolved since the late 1990s. Dilek Yankaya, Yeni İlami Burjuvazi (Istanbul: IletişimYayınları, 2013).

41 For the feminist critique of Kemalist statist feminism, see the pioneering work of Şirin Tekeli, ed., Women in Modern Turkish Society: A Reader (London and New York: Zed Books, 1995).

42 Güneş Ayata and Tütüncü, "Party Politics of the AKP."

43 Zehra Yılmaz, Dişil Dindarlık: İslâmcı Kadın Hareketinin Dönüşümü (Istanbul: Iletişim Yayınları, 2015).

44 Yeşim Arat, "Islamist Women and Feminist Concerns in Contemporary Turkey Prospects for Women's Rights and Solidarity," Frontiers 37, no. 3 (2016): 125-50.

45 Ayata and Tütüncü, "Party Politics of the AKP"; Cindoğlu and Unal, "Gender and Sexuality"; Kurtuluş Korkman, "Blessing Neoliberalism". 
ensure healthy generations are raised and families find happiness. It is clear that the party program and election declaration combines a liberal perspective, which wants women to take social responsibility and be active, with a conservative narrative line, which is collectivist and family-centered. Particularly those statements that put the burden of social problems on the shoulders of the family, and in turn on women, address the family as the core unit fulfilling social integration and in the management of social risks.

With the burden of the EU-led democratization process and increasing social demands (thanks also to the women's movement(s) in Turkey), the AKP conducted liberal reforms to cope with the problem of "gender inequality" and to further integrate gender equity into the legislative structure. In January 1998, the Turkish Parliament adopted the first-ever law on domestic violence entitled the "Law on the Protection of the Family No. 4320." This law established a protection order system. A comprehensive National Action Plan for Combatting Violence Against Women 2007-10 was prepared accordingly and became effective in 2007. In 2012, Turkey was the first country to ratify the Council of Europe Convention on Preventing and Combating Violence Against Women and Domestic Violence, also known as the Istanbul Convention. The same year the government passed Law Number 6248 to Protect the Family and Prevent Violence Against Women and introduced gender equality policies. ${ }^{46}$ The constitutional changes of 2004 and 2010 confirmed the state's commitment to women's problems and extended constitutional guarantees of positive discrimination for women. However, among all these official reforms, which were also assessments of the EU membership process, the most important field that the government focused on in this first period was women's participation in labor. With the amendments to the Labor Law (2003), the government proceeded to expand the participation of women into work life by promoting a legal framework that favored women's paid employment, prevented sexual discrimination at work, and secured the principles of "equal pay for equal work" and "merit." To increase the ability of women to be involved in the labor market, some poverty alleviation policies (e.g. direct financial aid to lower-class women) and new nationwide campaigns to bridge the gap in the schooling of boys and girls were employed.

One can also analyze statements by Nimet Çubukçu, the state minister in charge of women, family, and children (between 2005 and 2009), who focused on women's declining employment rates and frequently complained about the lack of particular mechanisms that would enable women to enter the labor market. For Çubukçu, although equality has been legally established there

46 Elif Gözdasoglu Küçükalioglu, "Framing Gender-Based Violence in Turkey," Transformations of the Gender Regime in Turkey, ed. Azadeh Kian and Buket Turkmen, Les Cahiers du CEDREF, 22 (2018), 128-57. 
is still a problem due to the rapid increase in rural-urban migration and urban population, the reduction in the level of agricultural employment, the overall increase in the unemployed population and parallel contraction of work areas, extended periods of education, and the existence of informal economy. ${ }^{47}$ Later, in 2008, Çubukçu attended the meeting "Women in Business" organized by the Turkish Enterprise and Business Confederation (TÜRKONFED) where she invited all stakeholders to cooperate in order to increase women's employment rate by pointing out that women should not be considered "a cheap material for the informal economy." However, she defended the employment of women as flexible labor as a way to increase women's employment, let alone seeing any harm in it. Similarly, Çubukçu led the preparation of the 9th Development Plan for 2007 to 2013, which underlines that flexible working should be popularized to encourage women's participation in employment.

During the first Congress of Women Entrepreneurs Board of the Union of Chambers and Stock Exchanges, held with 700 women entrepreneurs in 2008, Çubukçu stated, "women, being limited by traditional values to responsibilities of the private life, are prevented from enjoying those opportunities offered to men in social and cultural areas," and pointed out "the male dominance in financial fields as the reason why women entrepreneurs are less despite the absence of any legal obstacle." She said the mindset on the way to the EU also needed to change, telling women "it is a fair competition and you can win as well" and making them run into invisible glass walls, so women needed certain positive support in some areas, and education in particular. Çubukçu pointed out how some women entrepreneurs around Anatolia had become successful "role models," and she was confident that "welleducated, hard-working, confident, selfless, and successful women" could make their presence felt in business and that their presence would grow. In educational campaigns like "Haydi Kızlar Okula," we find a similar storyline that implies "it is possible to win and be successful" in the shifting global economy, if you really believe and work hard. So, these obedient but hard-working girls and women who have succeeded based on self-performance and care in the sphere of education or at work are turned into prototypes for possible success stories of women and girls in Turkey's neoliberal times.

As has been addressed by the Women's Labor and Employment Initiative, the ongoing macroeconomic reformist policies of the government could not generate regular and secure employment since it did not have a critique of the male-dominant structure (i.e. structural gender inequalities and

47 "Çubukçu: Eğitimsiz kadınlar ev kadını," Politika Haberleri, December 31, 2005, https://www.mynet. com/cubukcu-egitimsiz-kadinlar-ev-kadini-110100192322; and "Çubukçu: Kadınların İşgücüne Katılımı Düşük," Bianet, July 14, 2005. 
discrimination, sexist division of labor, and masculine mindset restricting women's freedom of movement and decision making) as an obstacle to women's participation in employment. In other words, in such programs the problem of female poverty or lack of employment is represented as detached from the general context of structural inequalities at the intersection of class, gender, and ethnic divisions. The main solution proposed by the government's programs was "flexibility." However, we know that women doesn't only swell the ranks of poorly paid, insecure workers in the formal sector, they also constitute the majority of those who are self-employed or underemployed. As Schild states in the context of Chile, the motto of "flexibility" is the grim reality of this unregulated, self-exploitative work that women have been carrying out in these areas. ${ }^{48}$ Furthermore, as Rottenberg states, from this neoliberal-feminist position, balancing the roles of being a traditional housewife and a professional career-seeking woman is defined as the responsibility of female individuals with no help from men or the state/formal institutions. Here the AKP's neoliberal feminism emphasizes the role of the family and women's self-empowerment in her self-care and society's well-being, which is increasingly predicated on crafting what Rottenberg calls a happy workfamily balance. In addition to all these there is also the radically decontextualizing discourse on the success of women that represents a solidification of the neoliberal preoccupation with individualizing (antisocial and anti-political) logics that inculcate women to continually readapt and reinvent themselves to the shifting conditions of competitive market relations and globalization. This is "free market feminism," as described by McRobbie (2004), or neoliberal feminism, where the rural girls of educational campaigns or urban women of credit programs have become the new pinups for neoliberal and neoconservative dreams of winning and "just doing it" against the odds.

I call this mode of gender politics neoliberal feminism and stress the first component of this combination. The AKP initially did not appear to consider the conservation of female bodies and sexuality in Islamic moral terms as an urgent public-political issue, although this conservative discourse has always retained in its political baggage. For instance, it did not raise the "headscarf" issue as its main public problem requiring an urgent solution. As opposed to the pious women who occupied streets and university campuses for a very heated and lively struggle to force the secular power groups to retreat from their anti-headscarf position in the late 1990s, the AKP's female MPs, who neither wore headscarfs nor had faith-based lives, openly announced their change of view on this matter and decision to avoid such conflicts. This is what

48 Verónica Schild, "'Gender Equity' without Social Justice: Women's Rights in the Neoliberal Age," Nacla, September 25, 2007. 
Turam calls the "politics of non-defiance" 49 or what I call the "strategy of de-emphasizing conservative gendered body politics." Another case that exemplifies the same strategy concerns the government's policies on reproduction and abortion. Also in the same years, the government did not pursue a conflict-ridden policy but partially opened the way for secular-feminist women's organizations and discourses within the framework of the EU accession process. ${ }^{50}$ Concerning the actual subjective effects of the AKP's very eclectic discourse, one can gain some insight into how the husk of liberalism has been mobilized to spawn a neoliberal feminism, which in turn have been very articulative not only for the new feminist subject positions among neoliberal and neoconservative women/men, but also in the constitution of the AKP's image as liberal-reformative and the constitution of the new political alliance around its "Conservative Democracy" project.

\section{The authoritarian attempt of the AKP to clean the discursive field from other secular feminisms in the postfeminist period}

The global economic crisis (2007-8) that led to the post-2008 shifts in the socio-economic, legal, and political landscapes at the global scale had an important impact on the AKP's tendency to proceed toward authoritarianism. ${ }^{51}$ Bruff and Tansel argue that "the crisis and its accompanying aftershocks at various levels of governance and across a range of societies did play an important role in heightening the extant anti-democratic tendencies of neoliberalism and generating new mechanisms that reproduce and strengthen such tendencies." ${ }^{52}$ In the case of Turkey, it was not until the end of 2007 when some signs of an authoritarian turn from neoliberal-reformist politics to increasingly intolerant and aggressive politics against oppositional views in the AKP's rule became visible; particularly in the aftermath of the 2010 constitutional referendum and the general election of 2011, this new tendency became explicitly apparent.

During these years, in addition to the Gezi Protests, the failure of the AKP's so-called democratic package to solve the Kurdish problem and to

49 Berna Turam, "Turkish Women Divided by Politics," International Feminist Journal of Politics 10, no. 4 (December 2008): 475-94.

50 Melinda Negrón-Gonzales, "The Feminist Movement."

51 lan Bruff and Cemal Burak Tansel, "Authoritarian Neoliberalism: Trajectories of Knowledge Production and Praxis," Globalizations 16, no. 3 (2019): 233-44; Cemal Burak Tansel, "Authoritarian Neoliberalism and Democratic Backsliding in Turkey: Beyond the Narratives of Progress," South European Society and Politics 23, no. 2, (2018): 197-217; Özlem Kaygusuz, "Authoritarian Neoliberalism and Regime Security in Turkey: Moving to an 'Exceptional State' under AKP," South European Society and Politics 23, no. 2, (2018): 281-302.

52 Bruff and Tansel, "Authoritarian," 3-4. 
conduct a peace process had further aroused socio-political tension. Also, during the same years the coalition of Gülen's community with Erdoğan's group in the AKP fell apart. This process of a dismantling power block and social consensus around the "Conservative Democracy" project has happened while the AKP's strategic commitment to the EU process along with its liberal ethos has also gradually waned. All these resulted in changes in the AKP leaders' political discourses and led it to search for a new strategic alliance with more radical nationalist and conservative groups who were unhappy with the previous reformist and EU-oriented perspective of the government. In this process one can easily trace the gradual constitution of "regime security" and the neoliberal security state. ${ }^{53}$ There are different views on this matter. For instance, Köker sees the regime as more severely problematic and defines it as a variant of fascism, while Tuğal suggests we should use the term "neofascism" in analyzing it. $^{54}$

Independent from the question of how to define the new regime, it is certain that this new state project and emerging political regime in the aftermath of the AKP's drift toward authoritarianism was very gendered. This shift came into being with further attempts not only to widen what Petö calls a polypore state, ${ }^{55}$ which includes another civil society parallel to earlier secular ones, but also the destruction of the latter for the sake of the former under radical attacks of the government based on its security discourse and discourse of familialism. The AKP politicians, in alliance with the pro-AKP intellectuals and GONGOs (government-organized non-governmental organizations), ${ }^{56}$ further developed what I call a neoconservative feminist position, which has strong continuity with the earlier neoliberal-neoconservative one together with some important nuances. As opposed to its earlier liberal tune, this new political approach is based on what Kandiyoti calls "a politics of resentment that encourages the projection of hatred onto groups or communities seen as either privileged and exclusionary or as potentially treasonous (and sometimes both). The country's metropolitan, secular middle-classes have long been routine targets of this discourse." ${ }^{157}$

53 Kaygusuz, "Authoritarian."

54 Levent Köker, "Otoriter Rejimin Neresindeyiz?" Yarına Bakış, April 27, 2016, https://www.yarin abakis. com/2016/04/27/14542/; Cihan Tuğal, "In Turkey, the Regime Slides from Soft to Hard Totalitarianism," Open Democracy, 2016.

55 Andrea Petö, "Anti-gender Mobilisation in European Academia: Why we All Need to Be Concerned?" A public lecture organized by Belladona, Henrich Böll Foundation, and the University of Bremen, July 3, 2019, Bremen.

56 Çağla Diner. "Gender Politics and GONGOs in Turkey," Turkish Policy Quarterly 16, no. 4 (Winter 2918): 101-8.

57 Kandiyoti, "Locating the Politics of Gender," 105. 
Neoliberalism has not only deepened existing socio-political problems but provided legitimacy and a room for radical right-wing groups that had partially taken a step back when the AKP implemented its reform policies in the earlier period. However, in this later period the AKP began to appeal to the resentment felt by these radical groups and strengthened the conservative tune of its own alternative women's politics, allowing it to consolidate the new power block $^{58}$ while criminalizing other feminist or queer discourses. It has made use of the emergent moral crisis and created security narratives in the name of constituting an alternative gendered-patriarchal order. Of course, as Kandiyoti rightly underlines,

policing gender norms and enforcing conservative family values constitute central nodes of AKP ideology and practice in at least three crucial domains; first, in shoring up a populism that privileges gender as a marker of difference, pitting an authentically national "us" against an "anti-national" (gayri-milli) "them"; second, in the marriage of convenience between neo-liberal welfare and employment policies and (neo)- conservative familism; and finally, in the "normalization" of violence in everyday political discourse and practice. ${ }^{59}$

In this regime, what Acar and Altunok call the "politics of the intimate," 60 neo-conservative disciplinary power manifests itself in the regulation of women's bodies not only in terms of dress and behavioral codes but in intimate sexual relations, including reproductive choices, abortion, sexual orientation, and pre-marital sexuality. As Cindoğlu and Unal state, ${ }^{61}$ in this last decade of AKP's rule discourse on sexuality has proliferated at an unprecedented level in the political realm in Turkey. All these show that the AKP left its earlier strategy of deemphasizing the conservative definition of female sexuality and the female body in this period. Instead, it emphasized them in order to consolidate its exclusive discourses and strategies of otherness. In this postfeminist period $^{62}$ the clashes between different feminisms have become fairly visible and determinant, and gendered anti-genderism and anti-feminism (in terms of attacks against secular feminists and sometimes against the concepts of "gender" and "feminism" themselves) have functioned as a symbolic glue articulating the new power block against its opponents. ${ }^{63}$ Under these new

58 See Tuğal, "In Turkey, the Regime Slides."

59 Kandiyoti, "Locating the Politics of Gender," 105.

60 Acar and Altunok, "The 'Politics of Intimate'."

61 Cindoğlu and Unal, "Gender and Sexuality." See also Acar and Altunok, "The 'Politics of Intimate'."

62 Here the post-feminist period is defined as a period that presents a "complex representational terrain" that includes part backlash, part cultural diffusion, part repressed anxiety over shifting gender orders. See Phipps, The Politics of the Body.

63 Andrea Petö, "'Anti-gender' Mobilisational Discourse of Conservative and Far Right Parties As a Challenge for Progressive Politics," in Gender As Symbolic Glue: The Position and Role of 
circumstances, unlike the earlier period, the AKP's leading cadres began to promote their neoconservative understanding of women's issues destructively and used it as a weapon not only against secular feminists but also any group who is defined as an outsider of this holy community of "us" as the nation.

Gender norms (specifically women's conduct and propriety) do not only play a key role in delineating the boundaries between "us" and "them," but also help the authorities to mark who belongs to "the AKP-defined national community." Here the conservative notion of family also functions as a strong metaphor to define the nation which is based on a gendered discourse in which the ideal citizen is inscribed as a sovereign husband and his dependent wife/ mother rather than an individual, as Kandiyoti states. ${ }^{64}$ In line with this, White defines this new regime of the AKP as "big man politics." ${ }^{65}$ Here there is a "big man" or a "leader" who is envisioned as a father figure as well as a hero around which a hierarchy of networks characterized by personalized relations of support and obligation are evolved. All these explain why AKP politicians began to emphasize the conservative definition of femininity and feminine sexuality as a new affirmative strategy in attacking secular feminisms and replacing them with its highly illiberalized neoconservative feminist approach. It is a discursive strategy that has been particularly operationalized since 2007 by curtailing liberal elements of the earlier neoliberal feminist discourse for the sake of conservative ones.

These increasing illiberal, anti-democratic, and conservative gendered insights of the project can be traced in the AKP's political statements and policy documents. For instance, the government passed amendments in the period 2008 to 2014 that lifted the ban on using headscarves in public institutions, which was followed by the government's later attempts to elevate pro-natalist and pro-life stances and a series of provocative public statements on abortion by Erdoğan. He first said women needed to give birth to at least three children for the nation's future, which he claimed needed young, productive, and conservative next generations. Later in 2012, from a highly family-oriented and pro-life perspective blended with developmentalist-nationalist terms, in addition to making an analogy between abortion and the Uludere Massacre, he said that abortion was nothing but an insidious plan to eliminate our nation from the world stage. The leaders of the AKP dwelt further on the issue of the ban on wearing headscarves in educational institutions by saying it was not merely about the religious tradition, but a matter of basic human

Conservative and Far Right Parties in the Anti-gender Mobilizations in Europe, ed. Eszter Kováts and Maari Põim, FEPS in cooperation with the Friedrich-Ebert-Stiftung (2015), 126-32.

64 Kandiyoti, "Locating the Politics of Gender," 107.

65 Jenny White, "The Turkish Complex," The American Interest, 2015, http://www.the-american-interest. com/2015/02/02/the-turkish-complex/. 
rights. Women's "right" to have an abortion has also been reinterpreted from a very strict Islamic perspective as a "right" of the fetus. This interpretation of rights has become critical for the neoconservative feminism of the AKP. ${ }^{66}$ Here the conservative female body functions not only as a symbol of drawing borderlines that defined "us" as opposed to "them," but also as a means to moralize the crisis that Turkey was going through, since definitions of what are considered as threats to the nation state have been filtered through gendered and sexualized anxieties about national virility, sovereignty, and integrity ${ }^{67}$ All these were signs of an end to, to use Turam's phrase, the "politics of non-defiance" 68 and its replacement with a new strategy or "politics of defiance" that was functioning in line with the aggressive use of conservative values concerning femininity and female sexuality. While doing so, politicians were still appropriating liberal feminist concepts like rights and equality.

Like Christian conservatives, the AKP's conservatives do not argue for the superiority of men over women, but for their integral complementarity based on their biological and divinely ordained distinct natures (fitrat). Therefore it is not about equality but the concept of justice, which implies attributing equal values despite differences. The concept of justice in this sense has been used by intellectuals in the Islamic women's movement ${ }^{69}$ and implicitly acknowledged by AKP politicians from the very beginning. But AKP politicians began to defend this concept explicitly and systematically against the principle of equality starting from the late 2000s. For example, an initiative covered by the media as the Commission for "Equality of Women and Men" in 2005 was proposed in parliament by AKP officials to "exclude gender discrimination" from existing and draft laws. ${ }^{70}$ In this respect a body was set up as a requirement for EU accession. Although women's organizations wanted to name this body the Commission for Equality of Women and Men, the government prefers the Commission on Equal Opportunities for Women and Men. The latter implies that it is not about equality but making sure women and men, who are different by nature, have equal opportunities. ${ }^{71}$ Despite this earlier sign of its conservative agenda, it was only after 2010 when Prime

66 Cevahir Özgüler and Betül Yarar, "Neoliberal Body Politics: Feminist Resistance and the Abortion Law in Turkey," in Bodies in Resistance: Gender and Sexual Politics in the Age of Neoliberalism, eds. Wendy Harcourt, Silke Heumann, and Marjan Radjavi, 133-61 (London: Palgrave, 2016).

67 Kate Bedford, "Holding It Together in a Crisis: Family Strengthening and Embedding Neoliberalism," IDS Bulletin 39, no. 6 (December 2008): 60-6.

68 Turam, "Turkish Women Divided."

69 Zehra Yılmaz, Dişil Dindarlık.

70 "Kadın erkek eşitliği komisyonu kuruluyor," Hürriyet Haber, March 8, 2005.

71 See Pınar Illkkaracan, "Gender Equality Commission in Parliament After 10 Years of Women's Struggle," Bianet, February 9, 2009, https://bianet.org/english/women/112451-gender-equalitycommission-in-parliament-after-10-years-of-women-s-struggle. 
Minister Erdoğan personally pointed out the difference between these two concepts during his meeting with representatives of women's organizations held within the framework of the democratic initiative in Dolmabahçe Palace. He had said: "I already think women and men are not equal. That is why I prefer the term 'equal opportunities.' Women and men are different, but they complete each other." His words created a shocking effect and became the historical reference point in the change in the AKP's gender politics. ${ }^{72}$ After his first use of the term in 2010, in 2014 Prime Minister Erdoğan revisited the discussion of "equality" and "justice," and then used these phrases with new connotations:

What do women need? "Equality among women" and "equality among men" is more correct. However, what is particularly essential is women's equality before the justice. You cannot bring women and men into equal positions. [...] It is non-sense, against their fragile nature. [ ...] That is why we have to consider the concept of equivalence, or justice, rather than equality, as an important criterion in this matter. Our religion [Islam] has defined a position for women: Motherhood. [..] You cannot explain this to feminists because they don't accept the concept of motherhood. They care nothing about it. ${ }^{73}$

After this statement by Erdoğan, this conservative notion of "justice" has been more openly and systematically used against the concept of equality, which they blamed for being the tool of Western-minded secular feminists and Western politicians in misreading and refusing Islam. They argue that the notion of equality leaves women vulnerable to exploitation and abuse in society and at work. ${ }^{74}$

The year 2010 also appears to be an important turning point because from then on the AKP intensified its work and discourse on the family. ${ }^{75}$ Here the neoliberal objective of diminishing state responsibility for social protection comes increasingly with a discourse of "strengthening the family" to compensate for the retreat of the state. Hence the family once again turns into a locus of government intervention not only in pursuit of the "ideal" citizen-subject ${ }^{76}$ but also in regulating and coping with the unnamed crisis of neoliberalism. As

72 "Kadınla erkek eşit olamaz!" Gazetevatan.com, July 20, 2010.

73 "Erdoğan, Kadın-Erkek Eşitliği Fıtrata Ters," Son Dakika Haberler, November 25, 2014, https://www. hurriyet.com.tr/gundem/kadin-erkek-esitligi-fitrata-ters-27645541.

74 “Emine Erdoğan: 'Toplumsal Cinsiyet Adaleti İlkesini, Kadın-Erkek Eşitliğinin Temel Ölçüsü Yapmak Zorundayız," December 11, 2015, https://www.tccb.gov.tr/haberler/410/37251/emine-erdogantoplumsal-cinsiyet-adaleti-ilkesini-kadin-erkek-esitliginin-temel-olcusu-yapmak-zorundayiz.

75 Gülay Toksöz, "Transition from 'Woman' to 'Family': An Analysis of AKP Era Employment Policies from a Gender Perspective," Journal für Entwicklungspolitik 32, no. 1/2 (2016): 64-83.

76 Kandiyoti, "Locating the Politics of Gender," 107. 
explained above, neoliberalism causes crises but it is also informed by and through them. The clearest indicator of this familialism is the replacement of the Ministry of State for Women and Family with the Ministry of Family and Social Policies (MFSP), deleting the term "women" from the title in 2011. According to Akkan, "the establishment of the MFSP in 2011 was an important step, providing institutional autonomy for the implementation of explicit and integrated family policies." It also reflects the moment of transformation in which not only the AKP's new notion of "sacred familialism" but also family politics and policies have become explicit at the institutional level. ${ }^{77}$ Moreover, in the Ninth Development Plan for the period 2007-13 and the Tenth Development Plan of the period 2014-18, gender equality is not mentioned among the main goals. Rather, the Tenth Development Plan of 2014-18 emphasizes the protection and strengthening of the family rather than improving gender equality. To conclude, the main characteristics of the AKP's neoconservative feminism are twofold. It not only appropriates but also converts classical notions like freedom (religious), rights (of other subjects than women, i.e. Muslim women, fetuses, or men), and "justice" (with an emphasis on being equally valuable in reference to all being servants before divine rule and justice). While doing so it erodes connections between women's issues and structural power relations based on gender, ethnicity, and class inequalities.

\section{Conclusion}

In the first period of the AKP's rule the government took a liberal position suited to the general neoliberal framework of global and national politics. The AKP's attempt to construct a liberal alliance and get wider support for its regime at the international scale was partly successful thanks to its politics affiliated with a neoliberal-neoconservative feminist position. To be recognized as "Conservative Democratic" rather than an Islamist party, and consistent with its strategy of exploring feminist themes in its particular way and manner, initially the AKP implemented several important gender equality reforms under the EU umbrella and did not foreground its conservative view of femininity and female sexuality. The party's neoliberal feminism, while on the one hand promoting the idea of gender equality in the name of creating active and responsible women subjects, on the other hand put the burden of social problems on the shoulders of women and families. It avoided the challenging of existing structural inequalities and patriarchal structures. Neoliberalism in conjunction with neoconservatism has colonized public

77 Başak Akkan, "Politics of Care." 
spaces and discourses by producing its own variants not only of feministIslamic subjectivities but also of institutions and practices. As Rottenberg states regarding the development of neoliberal feminism in the USA, the neoliberal feminism of the AKP also "hollows out the potential of mainstream liberal feminism to underscore the constitutive contradictions of liberal democracy, and in this way further entrenches neoliberal rationality and an imperialist logic." Neoliberal social policies flavored with conservative values such as family, religion, and the (Islamic) community were presented as important in alleviating the harmful consequences of the neoliberal economy. Furthermore, calibrating a felicitous work-family balance has become the main task of women who are motivated to participate in work and social life. Despite its limitations, the AKP's women's rights discourse or its neoliberal feminism has at least become influential in mobilizing popular support for the AKP's earlier political project, which was seen as both modern and respectful to the tradition. This liberal gender discourse justified the modern and reformative character of the AKP in the eyes of the public in both Turkey and the West, differentiating the party from its conservative precursors, but it also passivized (but did not suppress) both radical Islamism and secular-feminist discourses.

However, in the later period, due to the changes in the balance of power at both the national and global level, the AKP had to retreat from its liberal and reformist position and tended to rely more and more on the use of state forces and of a political alliance including radical nationalist and conservative groups. During this later period, the already existing authoritarian-conservative tendency in the AKP's politics got stronger in parallel with the increasing crisis of neoliberalism with a human face (or a woman-friendly face), which once gave wider legitimacy to radical nationalist and conservative forces along with democratic progressive ones in the world.

This process has gone on in parallel with some changes in the government's gender politics that resulted in a more cohesively conservative discourse on women's issues. This is what I call the neoconservative feminism of the $\mathrm{AKP}$, and it functioned again as a glue consolidating its power block comprising radical nationalist and conservative groups. It also functioned in arousing moral outrages attributed to the national others and in providing gendered conservative solutions to the crisis. As the AKP shifted its modality of politics toward authoritarian oppositional politics, which was centered upon the binary "us" versus "them," the new basic strategy of the AKP was to revive the traditional definition of femininity and female sexuality, which can account for right-wing conservative forces targeting secularists and the non-Muslim Western world as enemies of Muslim populations and societies. Moreover, their attempt to recreate an Islamic version of liberal feminism within the 
frame of neoliberalism has gone too far with a desire to impose this Islamic and conservative feminism on other public discourses in a destructive manner. In this respect, the strategies of deemphasizing conservative femininity and female sexuality and of achieving a liberal partnership have been replaced with the strategy of increasing emphasis on conservative body politics. In other words, although the AKP has retained its reformist attitude, the conservative definition of female sexuality has been foregrounded to draw subjective and institutional boundaries in the process of constituting a new neoconservative feminism and drifting toward authoritarianism.

\section{References}

Acar, Feride and Gülbanu Altunok. "The 'Politics of Intimate' at the Intersection of Neo-liberalism and Neo-conservatism in Contemporary Turkey." Women's Studies International Forum 41 (2013): 14-23.

Akdoğan, Yalçın. AK Parti ve Muhafazakar Demokrasi. Istanbul: Alfa Yayınları, 2004.

Akgöz, Görkem. "Mutsuz Evlilikten Tehlikeli Flörte: Feminizm, Neoliberalizm ve Toplumsal Hareketler." $F e$ Dergi 8, no. 2 (2016): 86-100.

Akkan, Başak. "Politics of Care in Turkey: Sacred Familialism in a Changing Political Context." Social Politics: International Studies in Gender, State and Society 25, no 1 (Spring 2018): 72-91.

Arat, Yeşim. "Islamist Women and Feminist Concerns in Contemporary Turkey Prospects for Women's Rights and Solidarity." Frontiers 37, no. 3 (2016): 125-50.

Aslan, Özlem and Zeynep Gambetti. "Source Provincializing Fraser's History: Feminism and Neoliberalism." History of the Present 1, no. 1 (Summer 2011): 130-47.

Bedford, Kate. "Holding It Together in a Crisis: Family Strengthening and Embedding Neoliberalism." IDS Bulletin 39, no. 6, (December 2008): 60-6.

Brown, Wendy. "American Nightmare: Neoliberalism, Neoconservatism and De-democratization." Political Theory 34, no. 6 (December 2006): 690-714.

—. "Neoliberalism and the End of Liberal Democracy." In Edgework: Critical Essays on Knowledge and Politics, 37-59. Princeton: Princeton University Press, 2009.

—. "Neoliberalism's Frankenstein: Authoritarian Freedom in Twenty-First Century 'Democracies'." Critical Times 1, no. 1 (2018): 60-79.

Bruff, lan and Cemal Burak Tansel. "Authoritarian Neoliberalism: Trajectories of Knowledge Production and Praxis." Globalizations 16, no. 3 (2019): 233-44.

Butler, Judith. Gender Trouble: Feminism and the Subversion of Identity. London: Routledge, 1990-2006.

Buttigieg, Joseph A. "Contemporary Discourse on Civil Society: A Gramscian Critique." Boundary 2 32, no. 1 (2005): 33-52.

"Gramsci on Civil Society." Boundary 2 22, no. 3 (1995): 1-32.

Cindoğlu, Dilek and Didem Unal. "Gender and Sexuality in the Authoritarian Discursive Strategies of 'New Turkey'." European Journal of Women's Studies 24, no. 1 (2016): 39-54.

Colley, Linda and Catherine White. "Neoliberal Feminism: The Neoliberal Rhetoric on Feminism by Australian Political Actors." Gender Work and Organization 26, no. 8 (August 2019): 1083-99.

Coşar, Simten and İnci Özkan-Kerestecioğlu. "Feminist Politics in Contemporary Turkey: Neoliberal Attacks, Feminist Claims to the Public." Journal of Women, Politics \& Policy 38, no. 2 (2016): 151-74.

Coşar, Simten and Metin Yeğenoğlu. "New Grounds for Patriarchy in Turkey? Gender Policy in the Age of AKP." South European Society and Politics 16, no. 4 (2011): 555-73.

Coşar, Simten and Gamze Yücesan-Özdemir. Iktidarın Şiddeti: AKP'li Yıllar, Neoliberalizm ve İslamcı Politikalar. Ankara: Metis Yayınevi, 2014. 
Dağı, İhsan. "The Justice and Development Party: Identity, Politics, and Discourse of Human Rights in the Search for Security and Legitimacy." In The Emergence of a New Turkey: Democracy and the AK Parti, ed. H. Yavuz, 88-106. Salt Lake City: Utah University Press, 2006.

Deveaux, Monique. "Feminism and Empowerment: A Critical Reading of Foucault Author(s)." Feminist Studies 20, no. 2 (1994): 223-47.

Diner, Çağla. "Gender Politics and GONGOs in Turkey." Turkish Policy Quarterly, 16 no.4, (Winter 2018): 101-8.

Eisenstein, Hester. Feminism Seduced: How Global Elites Use Women's Labor and Ideas to Exploit the World. Boulder, CO: Paradigm Publishers, 2009.

Elson, Diane. "Male Bias in Structural Adjustment." In Women and Adjustment Policies in the Third World, eds. H. Afshar and C. Dennis, 46-68. New York: St. Martin's, 1992.

Foucault, Michel. Discipline and Punish: The Birth of the Prison. London: Penguin, 1978.

- The History of Sexuality Volume I: An Introduction, trans. Robert Hurley. New York: Pantheon Books, 1978.

The History of Sexuality: The Will to Knowledge. London: Penguin, 1998.

. "On the Genealogy of Ethics: An Overview of Work in Progress." In Ethics, Subjectivity and Truth: The Essential Works of Foucault, 1954-1984 Volume 1, ed. Paul Rabinow, trans. Robert Hurley et al. New York: The New Press, 1997.

Fraser, Nancy. "Feminism, Capitalism and the Cunning of History." New Left Review 56 (March-April 2009): 97-117.

—. "Feminist Politics in the Age of Recognition: A Two-Dimensional Approach to Gender Justice." Studies in Social Justice 1, no. 1 (2007): 23-35.

- Fortunes of Feminism: From State-Managed Capitalism to Neoliberal Crisis. London and New York: Verso, 2013.

Gleeson, Kate. "Abortion and 'Choice' in the Neoliberal Aftermath." Politics and Culture: Materialist Feminisms Against Neoliberalism (March 9, 2014), https://politicsandculture.org/2014/03/09/ abortion-and-choice-in-the-neoliberal-aftermath-by-kate-gleeson/.

Göle, Nilüfer. İslamın Yeni Kamusal Yüzleri. Istanbul: Metis Yayınları, 2000.

—. Modern Mahrem. Istanbul: Metis Yayınları, 1991.

Güneş Ayata, Ayşe and Fatma Tütüncü. "Party Politics of the AKP (2002-2007) and the Predicaments of Women at the Intersection of the Westernist, Islamist and Feminist Discourses in Turkey." British Journal of Middle Eastern Studies 35, no. 3 (2008): 363-84.

Hall, Stuart and Alan O'Shea. “Common-Sense Neoliberalism.” Soundings 55 (2013): 9-25.

Jaworska, S. and Krishnamurthy, R. "On the F Word: A Corpus-Based Analysis of the Media Representation of Feminism in the British and German Press Discourse, 1990-2009." Discourse and Society 23, no. 4 (2012): 401-31.

Jessop, Bob. "New Labour or the Normalization of Neoliberalism." British Politics 2, no. 3, (2007): 282-88.

_ . "The Third Way: Neo-liberalism with a Human Face?" In New Labour und die Modernisierung Gross Britanniens, eds. Sebastian Berg and Andre Kaiser, 333-66. Augsberg: Wissener Verlag, 2006.

Kandiyoti, Deniz. "Locating the Politics of Gender: Patriarchy, Neoliberal Governance and Violence in Turkey." Research and Policy on Turkey 1, no. 2 (2016): 103-18.

Kaygusuz, Özlem. "Authoritarian Neoliberalism and Regime Security in Turkey: Moving to an 'Exceptional State' under AKP." South European Society and Politics 23, no. 2 (2018): 281-302.

Kurtuluş Korkman, Zeynep. "Blessing Neoliberalism: Economy, Family, and the Occult in Millennial Turkey." Journal of the Ottoman and Turkish Studies Association 2, no. 2 (2015): 335-57.

Küçükalioglu, Elif Gözdasoglu. "Framing Gender-Based Violence in Turkey." Transformations of the Gender Regime in Turkey, ed. Azadeh Kian and Buket Turkmen, 128-57. Les Cahiers du CEDREF, 22 (2018). Laclau, Ernesto and Chantale Mouffe. Hegemony and Socialist Strategy: Towards a Radical Democratic Politics. London and New York: Verso, 1985.

Lemke, Thomas. “The Birth of Bio-politics': Michel Foucault's Lecture at the Collège de France on Neo-liberal Governmentality." Economy and Society 30, no. 2 (2001): 109-207. 
McGuire, Thomas. "Social Justice Feminism and Its Counter-Hegemonic Response to Laissez-Faire Industrial Capitalism and Patriarchy in the United States, 1899-1940." Studies in Social Justice 11, no. 1 (2017): 48-64.

McLaren, A. Margaret. Feminism, Foucault, and Embodied Subjectivity. Albany, NY: SUNY Press, 2007.

McNay, Lois. Foucault and Feminism: Power, Gender and the Self. Cambridge: Polity Press, 1992.

McRobbie, Angela. The Aftermath of Feminism: Gender, Culture and Social Change. London: Sage, 2010.

_. "Notes on Postfeminism and Popular culture: Bridget Jones and the New Gender Regime." In All About the Girl: Culture, Power and Identity, ed. A. Harris, 3-14. New York: Routledge, 2004.

Molyneux, Maxine. 'The 'Neoliberal Turn' and the New Social Policy in Latin America: How Neoliberal, How New?" Development and Change 39, no. 5 (2008): 775-97.

Negrón-Gonzales, Melinda. "The Feminist Movement During the AKP Era in Turkey: Challenges and Opportunities." Middle Eastern Studies 52, no. 2 (2016): 198-214.

Oksala, Johanna. "Feminism and Neoliberal Governmentality." Foucault Studies 16 (2013): 32-53.

Öniş, Ziya. "Sharing Power: Turkey's Democratization Challenge in the Age of AKP Hegemony." Insight Turkey 15, no. 2 (2013): 103-22.

Özgüler, Cevahir and Betül Yarar. "Neoliberal Body Politics: Feminist Resistance and the Abortion Law in Turkey." In Bodies in Resistance: Gender and Sexual Politics in the Age of Neoliberalism, eds. Wendy Harcourt, Silke Heumann, and Marjan Radjavi, 133-61. London: Palgrave, 2016.

Özuğurlu, Aynur. 21. Yüzyıl Feminizmine Doğru: Neoliberalizmin Ötesinde Bir Kadın Hareketi Için Tartışmalar. Ankara: NotaBene Yayınları, 2013.

. "Neoliberalizm ve Feminist Politikada 'Sınıfsal Tutum' Arayışları." Ankara Üniversitesi SBF Dergisi 67, no. 4 (2012): 125-46.

Pető, Andrea. "'Anti-gender' Mobilisational Discourse of Conservative and Far Right Parties As a Challenge for Progressive Politics." In Gender As Symbolic Glue: The Position and Role of Conservative and Far Right Parties in the Anti-gender Mobilizations in Europe, eds. Eszter Kováts and Maari Põim, 126-32. FEPS in cooperation with the Friedrich-Ebert-Stiftung (2015).

Phipps, Allison. The Politics of the Body: Gender in a Neoliberal and Neoconservative Age. Cambridge: Polity Press, 2014.

Ringrose, Jessica. "Successful Girls? Complicating Post-feminist, Neoliberal Discourses of Educational Achievement and Gender Equality." Gender and Education 19, no. 4 (2007): 471-89.

Rottenberg, Catherine. "The Neoliberal Feminist Subject." LARB (Los Angles Review of Books), January 7, 2018, https://lareviewofbooks.org/article/the-neoliberal-feminist-subject/

. "The Rise of Neoliberal Feminism." Cultural Studies 28, no. 3 (2014): 418-37.

Sawicki, Jana. "Foucault and Feminism: Towards a Politics of Difference." Hypatia 1, no. 2 (1986): 23-36.

Tansel, Cemal Burak. "Authoritarian Neoliberalism and Democratic Backsliding in Turkey: Beyond the Narratives of Progress." South European Society and Politics 23, no. 2, (2018): 197-217.

Tekeli, Şirin (ed.) 1995. Women in Modern Turkish Society: A Reader. London and New York: Zed Books. Toksöz, Gülay. "Transition from 'Woman' to 'Family': An Analysis of AKP Era Employment Policies from a Gender Perspective." Journal für Entwicklungspolitik 32, no. 1/2 (2016): 64-83.

Tuğal, Cihan "Fight or Acquiesce? Religion and Political Process in Turkey's and Egypt's Neoliberalizations, Development and Change." International Institute of Social Studies 43, no. 1 (2012): 23-51.

Turam, Berna. "Turkish Women Divided by Politics." International Feminist Journal of Politics 10, no. 4 (December 2008): 475-94.

Walby, Sylvia. The Future of Feminism. Cambridge: Polity Press, 2011.

Yankaya, Dilek. Yeni İslami Burjuvazi. İstanbul: İletişimYayınları, 2013.

Yılmaz, Zehra. Dişil Dindarlık: İslâma Kadın Hareketinin Dönüşümü. Istanbul: Illetişim, 2015. 